\title{
Bacterial Ecology of the "Kaddid", Typical Dried Meat of the North Africa, During Its Traditional Fermentation
}

\author{
H. Mahdjoub Bessam ${ }^{1,2}$, M. Missouri ${ }^{1}$, S. Kridech ${ }^{3}$ \\ ${ }^{1}$ Department of Biology, Faculty of Natural Sciences \& Life, Djillali Liabes University of Sidi Bel-Abbes, Sidi Bel-Abbes, Algeria \\ ${ }^{2}$ Laboratory Eco Development of Areas, Faculty of Natural Sciences \& Life, Djillali Liabes University of Sidi Bel-Abbes, Sidi Bel-Abbes, \\ Algeria \\ ${ }^{3}$ Department of Biology, Faculty of Natural Sciences \& Life, Mustapha Stambouli, University of Mascara, Mascara, Algeria
}

Email address:

hassibabess22@yahoo.fr (H. M. Bessam)

\section{To cite this article:}

H. Mahdjoub Bessam, M. Missouri, S. Kridech. Bacterial Ecology of the "Kaddid", Typical Dried Meat of the North Africa, During Its Traditional Fermentation. Journal of Food and Nutrition Sciences. Vol. 4, No. 3, 2016, pp. 70-77. doi: 10.11648/j.jfns.20160403.15

Received: April 6, 2016; Accepted: April 25, 2016; Published: May 30, 2016

\begin{abstract}
The development of lactic fermentations for transformation and bio conservation of meat, part of the indigenous flora of the 'Kaddid' is very promotable, due to their adaptability to the conditions of fermentation. The objective of this study is the selection of indigenous strains of the Lactobacillus genus highly acidifying by phenotypic and biochemical methods. The selection focused on technological criteria, such as the ability to grow in an environments at $\mathrm{Ph} 7<\mathrm{T}>45^{\circ} \mathrm{C}, 4 \%<\mathrm{NaCl}<$ $10 \%$. The Lb Z meets most of the criteria, and the strain presents a rapid adaptability to the environment, and is equipped with proteolytic, lipolytic and antimicrobial activities against Staphylococcus strain aureus. Furthermore, the strain produces inhibitory substances of a proteic nature: in addition to lactic acid and hydrogen peroxide bacteriocins.
\end{abstract}

Keywords: 'Kaddid', Indigenous Lactic Ferments, Technological Properties, Acidification Activity, Antimicrobial Activity, Lactobacillus sakei

\section{Introduction}

In the food industry, the addition of microbial starters in meat has become more prevalent in recent years. For many products, this has allowed better control of the fermentation process and has prevented accidents related to the growth of undesirable microflora. The bacteria most commonly used as starters in the manufacture of fermented products are Lactobacilli such as Lb. plantarum, Lb. brevis, Lb. pentosus, Lb. curvatus, Lb. sakei, Lb. paracasei, Lb. farciminis... [1, 2].

Algerian traditional fermented products, commonly known as dried salted meat 'Kaddid' produced by hand at home for self-supply. The fact that the meat is salted dried or has undergone a lactic fermentation means that, pathogens are often inhibited [3, 4] 'Kaddid' is thus used as a biological material, in order to isolate strains of lactic acid bacteria. The development and industrial use of starters composed of indigenous bacteria could be promising. This approach prefigures a biotransformation and a bio-conservation of meat products through the addition of lactic ferments.

\section{Materials \& Methods}

\subsection{Preparation of the Biological Material}

The 'Kaddid"is prepared from fresh strips of Lamb (sheep breed OuledDjellal/ Algeria). They undergo a traditional method of conservation, including a salting and drying in the Sun.

\subsection{Isolation of Lactic Acid Bacteria Strains}

Enumeration and isolation is carried out on specific genres (Lactobacillus), or even specific strains (Lactobacillus sakei, Lactobacillus plantarum, Lactobacillus curvatus...). The Middle Man Regosa Sharpe (MRS) $\mathrm{pH}=5.4$ are chosen to allow selection and isolation of Lactobacillus [5].

\subsection{Purification of the Isolates of Lactic Acid Bacteria}

After incubation and observation, $\mathrm{Gram}^{+}$and catalase colonies are selected and subcultured on MRS medium liquid and solid $\mathrm{pH} 5,4$. The operation is renewed until a pure 
culture, strains of Lactobacillus sp retained and the genus Lactobacillus species studied in accordance with the Protocol based on key dictomiques [6].

\section{4. pH and Power Acidifier in MRS Broth of Pure Isolates}

A Strain producing a lot of lactic acid is considered to be efficient, it is impounded to the characterization and study of its antimicrobial activity against pathogenic indicator strains. Cultures are followed on medium MRS. liquid $\mathrm{pH}=6.4$, at $30 \pm 2^{\circ} \mathrm{C}$ [7]. To estimate the concentration of lactic acid produced (the molar concentration of ions $\mathrm{H}_{3} \mathrm{O}^{+}$) either in degrees Dornic $\mathrm{mg} / \mathrm{l}$, acidity titration is carried out on the culture.

\subsection{Biochemical Characterization}

Lactobacillus strains selected are all of bacilli $\mathrm{Gram}^{+}$, catalase (-). The Gram stain helps to distinguish two types of bacteria: those whose cell wall is rich in lipids (Gram negative G-) and those whose wall is poor (Gram positive $\mathrm{G}+$ ). Catalase is an enzyme present in most of the optional strict anaerobic and aerobic bacteria, its main function in cells is to prevent the accumulation levels toxic of hydrogen peroxide $\left(\mathrm{H}_{2} \mathrm{O}_{2}\right)$ formed as a by - product of metabolic processes. It catalyzes the conversion of hydrogen peroxide into water and oxygen that emerges.

\subsubsection{Study of Nitrogen Metabolism}

Search for arginine deshydrolase $\mathrm{ADH}$ on medium Moeller.

\subsubsection{Study of the Fermentative Power}

Production of carbon dioxide by hydrolyzing glucose on MRS. Glucose liquid medium in order to distinguish species the lactic acid bacteria homofermentaires [1].

The production of lactic acid from the fermentation of the 14 following sugars: arabinose, glucose, galactose, lactose, maltose, mannitol, sucrose, fructose, esculin, melibiose, ribose, mannose, sucrose, raffinose, is determined [8]. The fermentation of a strain tested profile is compared with profile types of classification of Bergey's manual bacteriology [9]. Complete characterization of our bacterial strains is completed according to the diagrams of systematic.

\subsection{Physiological Characterization}

The kinetics of growth at different temperatures [10], at different $\mathrm{NaCl}$ concentrations [6] and at different $\mathrm{pH}$ values was measured. The optical density (D.O) of the fermentation medium is measured by spectrophotometer an absorbance of $70 \%$ at $600 \mathrm{~nm}$ corresponds to $2 \times 10^{8} \mathrm{UFC} / \mathrm{ml}$.

The study of the antimicrobial power of strains is followed by putting in contact the supernatant of lactic-producing strain of antimicrobial substances with strain pathogenic [11].

The strains grown on MRS. liquid $\left(18\right.$ hours at $\left.30^{\circ} \mathrm{C}\right)$ were centrifuged at $8000 \mathrm{trs} / \mathrm{min} \times 10 \mathrm{~min}$, the supernatant is filtered (Millipore filter paper $0,45 \mu \mathrm{m}$ ), then submitted to the diffusion method in Wells on TSA (Tryptone, soy, Agar) medium for research of antimicrobial substances. Four suspension bacterial indicator tests were prepared (Staphylococcus aureus, Pseudomonasaeuroginosa, Bacillus subtilus, Escherichia coli) to inoculate TSA plate.

Wells surrounded by a clear halo in the culture of the indicator strain water and more than $2 \mathrm{~mm}$ in diameter were considered as positive [7].

\subsection{Technological Characterization}

\subsubsection{Antibiotic Susceptibility}

On agar Mueller-Hinton, strain was tested for its sensitivity to different antibiotics. (Spiramycine, Cefazolinepenicillin, ampicillin, Oxacillin, lincomycin, colistin, gentamicin, kanamycin, Amikacin, erythromycin, neomycin, Imipinem...). The results are expressed by an S for sensitive and R for resistant, as recommended by NCCLS (National Committee for Clinical Laboratory standards) [12].

\subsubsection{Proteolytic Activity}

The proteolytic activity of the strain is revealed by the method of the spots on MRS agar with $10 \%$ skim milk sterile ( 24 to $48 \mathrm{~h}$ at $30^{\circ} \mathrm{C}$ ). A positive result by a clear halo around the spot of seeding, the lack of it explaining the absence of proteolytic activity [13].

\subsubsection{Lipolytic Activity}

The lipolytic activity is detected, using the MRS agar medium supplemented with Tween 80 and Tween 20 (fatty acids). By the method of the spots on agar MRS ${ }_{\text {tween } 80,20}$. $(24$ to $48 \mathrm{~h}$ at $30^{\circ} \mathrm{C}$ ) the lipolytic activity, is revealed by an opaque outline of the spot [13].

\subsection{Antimicrobial Activity}

The nature of the inhibitory agent is sought, inhibition due to the production of organic acids, hydrogen peroxide and confirmation of the presence of inhibitory substances of proteinaceous bacteriocins [1].

\subsection{Conservation of Pure Strains}

The conservation of purified isolates is performed according to [14], $6 \mathrm{pm}$ on MRS broth culture is centrifuged at 4000 tours $/ \mathrm{min}$ for $10 \mathrm{~min}$. The recovered nerve is added to $2 \mathrm{ml}$ of sterile skimmed milk $30 \%$ glycerol. The samples are divided into Eppendorfs tubes and stored at $-20^{\circ} \mathrm{C}$.

Table 1. $p H$ and amount of lactic acid produced by 4 strains with a high acidifying power, grown on MRS medium liquid for $72 \mathrm{~h}$ at $30^{\circ} \mathrm{C}$.

\begin{tabular}{llll}
\hline Strain & $\mathbf{p H}$ & $\mathbf{~ m g / l}$ of medium & $\mathbf{D}^{\circ}$ \\
\hline $\mathrm{Lb} \mathrm{A}$ & 3,76 & 18,81 & 188,1 \\
$\mathrm{Lb} \mathrm{F}$ & 3,86 & 17,82 & 178,2 \\
$\mathrm{Lb} \mathrm{X}$ & 3,63 & 19,35 & 193,5 \\
$\mathrm{Lb} \mathrm{Z}$ & 3,56 & 19,8 & 198 \\
\hline
\end{tabular}

\section{Results}

\subsection{Identification and Selection of Isolates}

The tests reveal 20 isolates of the genus Lactobacillus $\mathrm{Gram}^{+}$, catalase ${ }^{-}$. Among them only 4 strains Lb A, Lb F, Lb 
$\mathrm{X}$ and Lb Z, prove to be more efficient and have significant acidification (table 1).

\subsection{Biochemical Characterization}

Strains of Lactobacillus Lb A, Lb F, Lb X-Lb Z, are bacteria Gram positive catalase negative.
The nitrogen metabolism (arginine deshydrolase $\mathrm{ADH}$ test) reveals3 $\mathrm{Lb} \mathrm{F}, \mathrm{Lb} \mathrm{X}$ and $\mathrm{Lb} \mathrm{Z}$ strains are $\mathrm{ADH}$ - except the $\mathrm{Lb}$ A strain, which is + DHA.

$\mathrm{Lb} \mathrm{A}, \mathrm{Lb} \mathrm{X}$ and $\mathrm{Lb} \mathrm{Z}$ are homofermentaires apart from the strain $\mathrm{Lb} \mathrm{F}$ which is heterofermentative.

Table 2. Profile fermentative isolates of Lactobacillus sp. Lb A, Lb F, Lb X and $\mathrm{Lb} Z$.

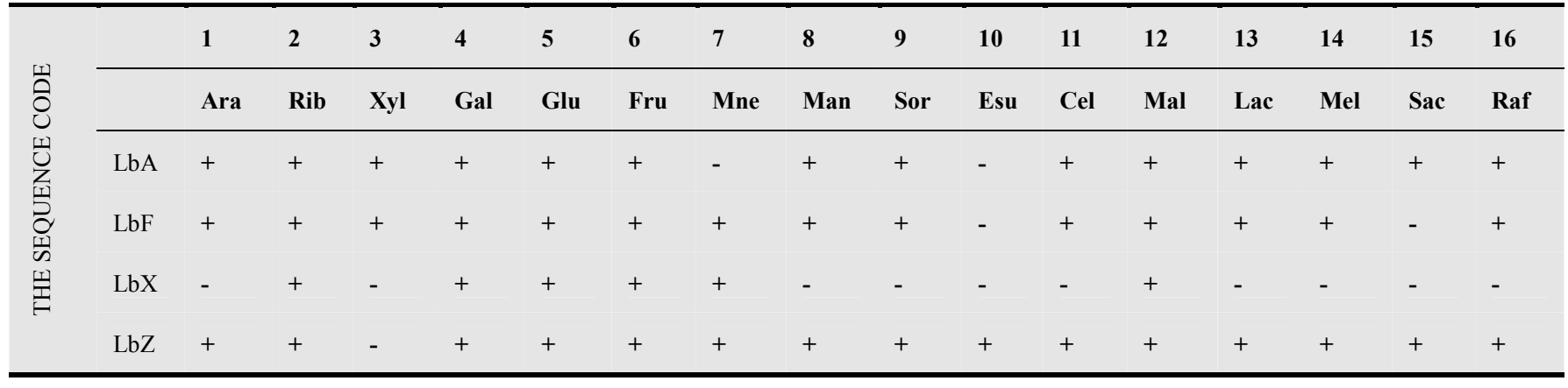

$\mathrm{Lb} \mathrm{Z}$-strain is able to ferment the entire series 16 tested sugars, for the determination of the fermentative, except for the sugar xylose profile. While other strains $\mathrm{Lb} \mathrm{A}, \mathrm{Lb} \mathrm{F}$ and $\mathrm{Lb} \mathrm{X}$ ferment all the sugars.

$\mathrm{Lb} \mathrm{Z}$-strain proves to be best adapted to the variations of carbohydrate sources. This persistence to discharge its energy and survive, regardless of the source and the duration of fermentation, could be a technological test.

\subsection{Physiological Characterization}

Growth in a complementary range to the fermentation profile, test to classify the Lactobacilli in three groups Streptobacterium, Betabacterium and Thermobacterium. Aside from the importance for the distribution of the Lactobacillus genus into three groups, the ability of the strain to grow in a range of $4^{\circ} \mathrm{C}$ to $45^{\circ} \mathrm{C}$ (cooling, drying and drying), is one of the criteria for the selection of a lactic ferment. The goal is to adapt to the conditions of manufacture of meat products and be more competitive during fermentation.

The results are translated into Figure 1 and 2, taking into account the bacterial concentration before and after incubation $(24 \mathrm{~h})$. The concentration of departure for each strain is of the order of $1.4 \times 10^{8} \mathrm{UFC} / \mathrm{ml}$ equivalent to a 0.5 D.O.

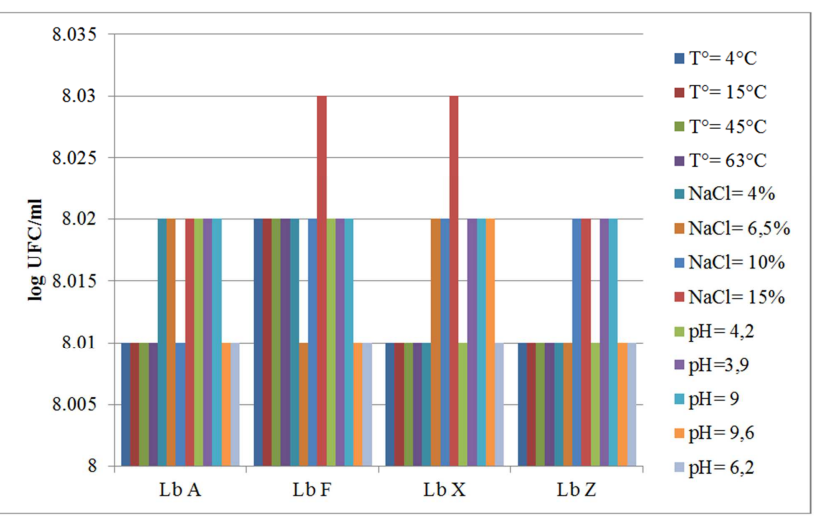

Figure 1. Growth of the strains $L b A, L b F, L b X$ and $L b Z$ to Temperature: $4^{\circ} \mathrm{C}, 15^{\circ} \mathrm{C} 45^{\circ} \mathrm{C}, 63^{\circ} \mathrm{C}$; Concentration of $4 \%, 6.5 \%, 10 \%$ and $15 \% \mathrm{NaCl}, \mathrm{pH}$ 3.9-4.2-9.0-9.6-6.2; time 0 h incubation.

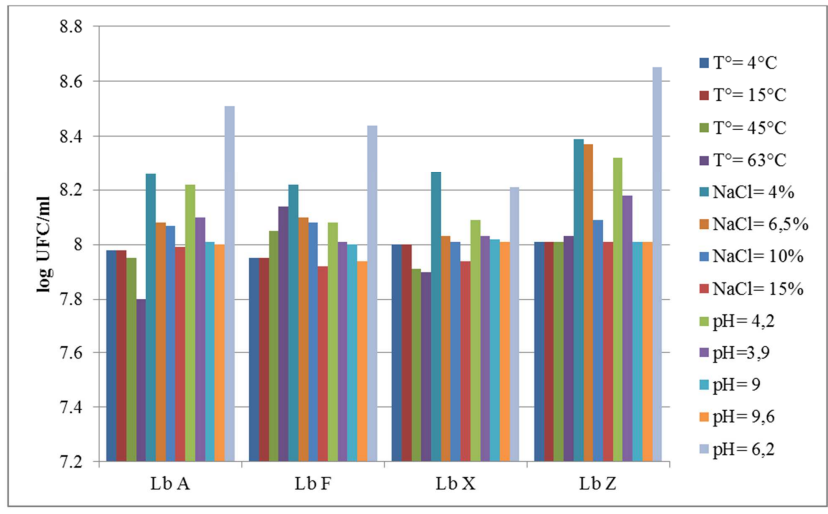

Figure 2. Growth of the strains $L b A, L b F, L b X$ and $L b Z$ to Temperature: $4^{\circ} \mathrm{C}, 15^{\circ} \mathrm{C} 45^{\circ} \mathrm{C}, 63^{\circ} \mathrm{C}$; Concentration of $4 \%, 6.5 \%, 10 \%$ and $15 \% \mathrm{NaCl}, \mathrm{pH}$ 3.9-4.2-9.0-9.6-6.2; time 24 hours of incubation.

On the basis of different temperatures for growth, the hydrolysis of arginine and the type of fermentation according to the used substrate (glucose or gluconate), the Lactobacillus genus is subdivided into three groups (Table 3 ).

Table 3. Different groups of the genus Lactobacillus.

\begin{tabular}{lllllll}
\hline \multirow{2}{*}{ Group } & \multicolumn{2}{l}{ Growth. } & \multirow{2}{*}{ ADH } & & \multicolumn{2}{l}{ Gas production } \\
\cline { 2 - 3 } \cline { 5 - 6 } & $\mathbf{\mathbf { 5 } ^ { \circ } \mathbf { C }}$ & $\mathbf{4 5}^{\circ} \mathbf{C}$ & & & Glucose & Gluconate \\
\hline Streptobacterium & + & $+/-$ & - & & - & + \\
Thermobacterium & - & + & - & - & - \\
Betabacterium & + & $+/-$ & + & + & + \\
\hline
\end{tabular}

The differentiation of the species of the genus Lactobacillus is essentially based on their ability to ferment carbohydrates differently (Table 2). The registered fermentation profiles (Table 2) are compared with those of the reference strains in the Bergey's identification key [6] then treated by BioMérieuxApiweb $^{\mathrm{TM}}$ software. This has led us to identify the different species of the genus Lactobacillus (Table 4). 
Table 4. Results of the identification of $L b A, L b F, L b X$ and $L b Z$ strains by comparison with the results of other authors and the repository table of [22].

\begin{tabular}{ll}
\hline The sequence code & Genus and species presumed \\
\hline Strain $\mathrm{Lb} \mathrm{A}$ & Lactobacillus plantarum à $75 \%[15]$ \\
$\mathrm{Strain} \mathrm{Lb} \mathrm{F}$ & Lactobacillus fermentum à $90 \%[15]$ \\
Strain $\mathrm{Lb} \mathrm{X}$ & Lactobacillus curvatus à $85 \%[16]$ \\
Strain Lb Z & Lactobacillus sakei à $95 \%$ [2] \\
\hline
\end{tabular}

\subsection{Characterization Technology of the Lb Z Strain Lactobacillus sakei}

Strain $\mathrm{Lb} \mathrm{Z}$ is able to grow at $4^{\circ} \mathrm{C}, 15^{\circ} \mathrm{C}$ and $45^{\circ} \mathrm{C}$, found property in mesophilic homofermentative to mannitol positive Lactobacilli group. Until this stage of characterization, $\mathrm{Lb} \mathrm{Z}$ strain proves to be more efficient and is able to grow in a varied range of temperature in relation to $\mathrm{Lb}$ A strains and Lb X.

\subsubsection{Growth at Different NaCl Concentration Test}

For the classification of Lactobacilli, the ability to grow and to resist different $\mathrm{NaCl}$ concentrations has its importance. The results obtained for the growth of the strains $\mathrm{Lb} \mathrm{A}, \mathrm{F}, \mathrm{Lb}$ $\mathrm{X} \mathrm{Lb}$ and $\mathrm{Lb} \mathrm{Z}$ at different concentration of $\mathrm{NaCl}$ deferred as Figure1and 2, reveal a $\mathrm{Lb} \mathrm{Z}$ strain able to grow in media containing concentrations of 4 to $10 \% \mathrm{NaCl}$, and persistent in a medium containing up to $15 \% \mathrm{NaCl}$. Strain $\mathrm{Lb} \mathrm{Z}$ meets the criterion sought to select a lactic ferment used in the meat processing industry.

\subsubsection{Test of Growth at Different pH Values}

After studying $\mathrm{Lb} \mathrm{A}, \mathrm{F}, \mathrm{Lb}$ X Lb and $\mathrm{Lb} \mathrm{Z}$ strains for their ability to grow at different $\mathrm{pH}$, growth of both strains $\mathrm{Lb} \mathrm{Z}$ and $\mathrm{Lb} \mathrm{A}$ results show that $\mathrm{Lb} \mathrm{Z}$ and $\mathrm{Lb} \mathrm{A}$ strains are resistant to acid stress compared to the other two strains Lb F and $\mathrm{Lb} \mathrm{X}$. There is therefore a suitable, mechanism by which the two strains are defending themselves.

\subsubsection{Study of the Kinetics of Acidification and Measurement of Growth in Pure Culture}

A ferment must dominate the flora and at a speed of more significant and steady growth than that of the natural flora, for this purpose, monitoring of growth kinetics is realized for 4 strains Lb A, Lb F, Lb X and Lb Z. Graphics (Figure 3 and 4), show the evolution of growth and the acidity function the time in a MRS modified (SB: similar broth). The absence of the lag phase or its shortening explains that originate in the strains studied a meat environment, and they are already adapted to these conditions. While the other 03 strains of Lactobacillus $\mathrm{Lb} \mathrm{A}, \mathrm{Lb} \mathrm{F}$ and $\mathrm{Lb} \mathrm{X}$ adapt to modified MRS medium, Lb Z -strain begins to grow in the early hours of incubation. The lack of lag in strain $\mathrm{Lb} \mathrm{Z}$, shows that the strain is more suitable and has no need to acclimatize to grow. $\mathrm{PH}$ values increased from 6.00 to 3.65 . According to the kinetics of growth of strain $\mathrm{Lb} \mathrm{Z}$, we note a development coupled with a decrease in $\mathrm{pH}$, regular. In the meat industry, the presence of strain $\mathrm{Lb} \mathrm{Z}$ would be privileged insofar as it allows obtaining the best organoleptic characteristics, without having any significant impact on the hygienic quality of meat products.

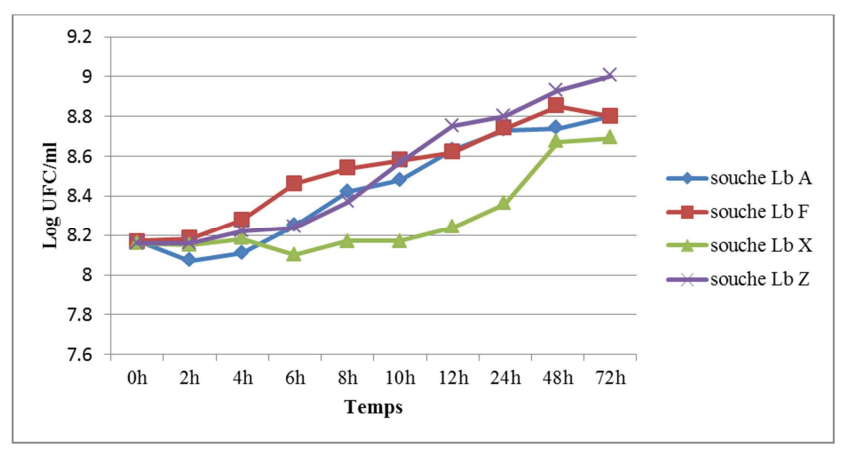

Figure 3. Evolution of growth $L b . A, L b F, L b X, L b Z$ strains at $30^{\circ} \mathrm{C}$ over time.

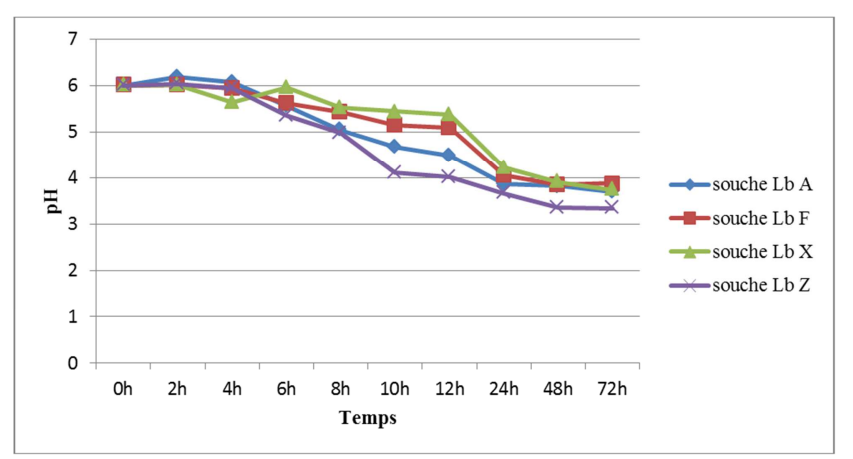

Figure 4. Changes in the acidity of $L b . A, L b F, L b . X, L b . Z$, strains to $30^{\circ} \mathrm{C}$ over time.

The results show that strain $\mathrm{Lb} \mathrm{Z}$ presents a character of speed to adapt and to acidify the Middle, saw its ability to grow in the presence of $\mathrm{NaCl}$ different concentrations, at different temperatures, to resist at low $\mathrm{pH}$ and its fermentation to several sources carbohydrate profile.

\subsubsection{Lb Z Strain Antibiotic Sensitivity}

The strain turns out to be very sensitive to Cefazolin $(30 \mu \mathrm{g})$ and Imipenem $(10 \mu \mathrm{g})$; sensitive to ampicillin $(10 \mu \mathrm{g})$, Oxacillin $(5 \mu \mathrm{g})$, gentamycin $(10 \mu \mathrm{g})$, Amikacin $(10 \mu \mathrm{g})$, erythromycin $(15 \mu \mathrm{g})$ and penicillin $\mathrm{G}(10 \mu \mathrm{g})$.

\subsubsection{Proteolytic Activity}

The presence of a clear halo around the spot of sowing (Figure 5), explains that Lb Z has enzymes, prognostic which gives it a proteolytic, character in the meat processing industry.

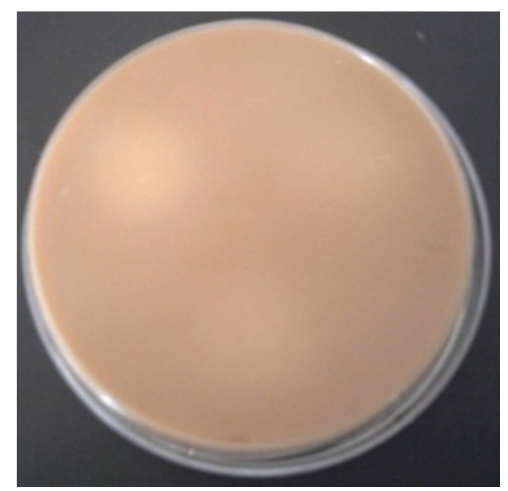

Figure 5. Proteolytic activity of strain test $\mathrm{Lb} Z$. 
The catabolism of amino acids can induce the formation of amino, ammonia or other products; some have aromatic properties.

\subsubsection{Lipolytic Activity}

Lb Z -strain shows a lipolytic character shown by an opaque halo around the sowing spot (Figure 6).

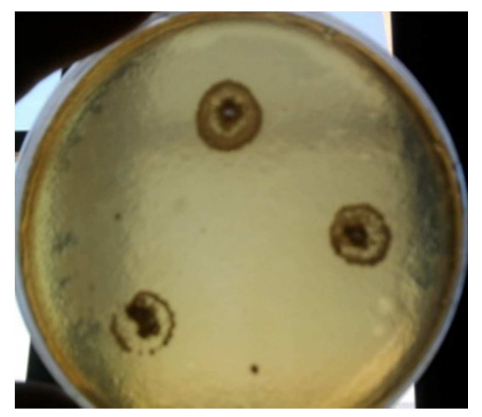

Figure 6. Strain Lb Z lipolytic activity test.

The lipolytic action of lactic acid bacteria plays a role in the aromatization of the product by producing aromatic volatile compounds.

\subsubsection{Highlighting Strain Lb Z Antimicrobial Activity the Activity of Strain}

$\mathrm{Lb} \mathrm{Z}$ is tested on 04 indicators to strains pathogenic: Escherichia coli, Pseudomonas aeruginosa, Bacillus subtilus and Staphylococcus aureus. The $\mathrm{Lb} \mathrm{Z}$ strain has proved to be more active on Staphylococcus aureus and Pseudomonas aeruginosa (figure 7).
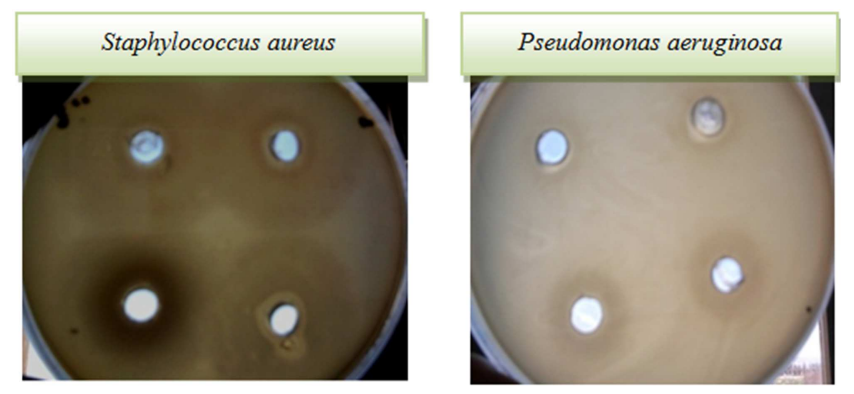

Figure 7. Indirect antimicrobial action (by the method of distribution wells of supernatant filtered via agar) strain Lb Z on Staphylococcus aureusand Pseudomonas aeruginosa.

\subsubsection{Highlighting the Nature of the Inhibitory Agent}

The inhibition may be due to the production of organic acids, hydrogen peroxide production or the presence of bacteriocins. The antimicrobial activity of strain $\mathrm{Lb} \mathrm{Z}$ test reveals that inhibition is visible, after neutralization of supernatant (elimination of the acid effect), after treatment of supernatant with the enzyme catalase (elimination of the effect of the $\mathrm{H}_{2} \mathrm{O}_{2}$ ), after neutralization of the two agents (acid + hydrogen peroxide), Strain Lb Z always has an effect on Staphylococcus aureus. The results obtained show that inhibiting substance may be proteinaceous, alleged bacteriocin, due to its sensitivity to high temperatures and its destruction by heating at $100^{\circ} \mathrm{C}$ for $15 \mathrm{~min}$.

\subsubsection{Research of Inhibitory Substances of Proteic Nature}

The inhibition halo disappears in the presence of the action of proteolytic enzyme (figure 8), the inhibitory agent is therefore proteinaceous. The loss of antimicrobial activity of supernatant after treatment with proteolytic enzymes (trypsin and $\alpha$-chymotrypsin and proteinase $\mathrm{K}$ ) shows the sensitivity of the active compounds secreted by cultured strains. Because bacteriocins are by definition protein substances, they must be sensitive to at least one enzyme. Accordingly, sensitivity to proteolytic enzymes is the main criterion in their characterization.

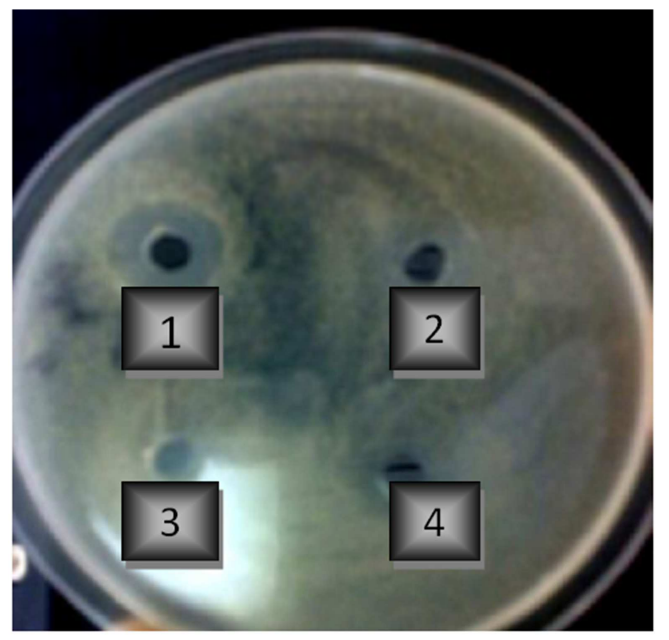

Figure 8. Action of proteolytic enzymes on the supernatant neutralized and processed by catalase 2 hours before use. $(1=$ Supernatant neutralized and processed by catalase 2 hours before use, $2=1+\alpha$-Chymotrypsin, $3=1+$ Trypsin, 4 = 1+ Proteinase K).

The results obtained show that a part of the antimicrobial activity of strain $\mathrm{Lb} \mathrm{Z}$ is due to protein substances of the bacteriocins.

\section{Discussion}

The work undertaken has retained 20 isolates of the genus Lactobacillus all Gram-positive, catalase negative, including representative 04 strains of the dominant flora identified by phenotypic methods and characterized based on technological criteria sought generally in the selection of lactic ferments to industrial interest.

Of the Lactobacillus isolated, only 4 strains $\mathrm{Lb} \mathrm{A}, \mathrm{Lb} \mathrm{F}$, $\mathrm{Lb} \mathrm{X}$ and $\mathrm{Lb} \mathrm{Z}$, prove more efficient and able to acidifying important Strain Lb Z appears to be the most suitable source oxidization variations, its ability to grow in a temperature of $4^{\circ} \mathrm{C}$ to $45^{\circ} \mathrm{C}$ (cooling, drying and drying) as well as the production of fast and regular lactic acid at the beginning of fermentation are important and desired criteria for the selection of a lactic ferment. Lactic acid contributes to inhibition of unwanted flores, to the development of the colour, texture and flavour of the product. Persistence for the duration of fermentation and maturing of the meat product, is a research technology test [17]. The goal is to adapt to the conditions of manufacture of meat products to be more competitive during fermentation. $\mathrm{Lb} \mathrm{Z}$ strain is therefore the 
most efficient research character, due to its ability to grow in a range of temperature varied from strains $\mathrm{Lb} \mathrm{A}$ and $\mathrm{Lb} \mathrm{X}$. The results obtained with strain $\mathrm{Lb} Z$, for the test of growth at a temperature of $45^{\circ} \mathrm{C}$ and thermo-resistance do not match those found by [18], dry sausage-specific strains are no growth. Strain $\mathrm{Lb} \mathrm{Z}$ homofermentative, remains always the most efficient, compared to the strain Lb F, even though it grows at high temperature, and is heterofermentative. The lactic acid bacteria species are not desired, because they produce a large amount of acetic acid inducing a pungent smell. In addition the formation of large quantities of $\mathrm{CO}_{2}$ generates the development of cavities in the finished product [2]. The resistance test reveals a positive maximum concentration of $\mathrm{NaCl}$, widely used salt in meat products, for its inhibitory property industry of unwanted flores $\mathrm{Lb} \mathrm{Z}$. Thus, a combination of salt with a lactic ferment would get a finished product with hygienic properties, using smaller quantities in salt than those used previously. The resulting product will conform to the consumption and satisfactory (prevention of the health problems for consumers). The combination "ferment lactic-salt" will also reduce the use of physical methods requiring much energy (freezing, irradiation, heating... etc) or chemicals, in the form of additives; aimed at the preservation of processed meat products. For concentrations of $10 \% \mathrm{NaCl}$, growth is observed for strain $\mathrm{Lb} \mathrm{Z}$, unlike the work of [18], which strains of Lactobacillus sakei isolated from a dry sausage had not the ability to grow in the presence of $10 \% \mathrm{NaCl}$. Strain $\mathrm{Lb} \mathrm{Z}$ meets the criterion sought to select a lactic ferment used in the industry of processing of meat, where the character of resistance to different concentrations of $\mathrm{NaCl}$ is important. As long as the biotransformation and bio-conservation of food continue to be a condition of fermentation, ferments are selected for their production of lactic acid and resistance at low $\mathrm{pH}$. Lactobacilli produce during the growth of the lactic acid which inhibits the development of unwanted flora for part in fermented products. Lactic acid exists in two forms: the non dissociated form $\mathrm{CH} 3 \mathrm{CHOHCOOH}$ (lactic acid) and the dissociated form $\mathrm{CH} 3 \mathrm{CHOHCOO} \mathrm{-} \mathrm{(lactate).} \mathrm{The}$ equilibrium between the two forms depends on the $\mathrm{pH}$ of the solution: the $\mathrm{pH}$ is low, more the non dissociated form is represented [19]. For resistance to acid stress, Lactobacilli adapting mechanism of resistance 'Acid Tolerance Response'(ATR) [10]. Having studied strains Lb A, Lb F, Lb $\mathrm{X}$ and $\mathrm{Lb} \mathrm{Z}$ for their ability to grow at different $\mathrm{pH}$, growth of both strains $\mathrm{Lb} \mathrm{Z}$ and $\mathrm{Lb} \mathrm{A}$ to obtained results, show that $\mathrm{Lb} \mathrm{Z}$ and $\mathrm{Lb}$ A strain are resistant to acid compared to the other two strains stress Lb F and Lb X. So there is a suitable, mechanism by which the two strains are defending themselves. The same results were reported by [15], which showed that Lactobacillus plantarum strain, isolated from dried salted meat, produced in a traditional Tunisian way, was able to grow in a medium acid at $\mathrm{pH}=3.9$ and 4.2. While [20] has shown that Lactobacillus plantarum strain poor growth strain Lactobacillus sakei able to grow at low $\mathrm{pH}$. [1] has shown that $90 \%$ of the strains of Lactobacilli homofermentaires or lactic acid bacteria optional believe at
$\mathrm{pH}=4.4$ whereas at $\mathrm{pH}=9$, no growth is observed consistent with our results. A ferment must dominate the flora at a speed of more significant and steady growth than that of the natural flora $[21,2]$. The evolution of growth and the acidity function the time in a MRS modified (SB: similar broth) as reported by [17], reveals the absence of the lag phase or its shortening; this explains that the strains are already adapted to these conditions. The absence of lag in strain $\mathrm{Lb} \mathrm{Z}$ phase, shows that it is better suited and has no need to acclimate to grow. PH values increased from 6.00 to 3.65. [20], this phase is 4 hours for the majority of the strains isolated from the dry sausage. According to the kinetics of growth of strain Lb Z, we note a development coupled with a decrease in regular $\mathrm{pH}$. In industry, the presence and the dominance of the Lb Z strain are privileged insofar as it allows us to obtain the best organoleptic characteristics, without having any significant impact on the hygienic quality of meat products. Little strains isolated from meat-based products, like Lactobacillus sakei, Lactobacillus curvatus and plantarum, are resistant to the antibiotic [22]. Because this resistance may be transmitted to the rest of the flora present in the same foodstuff [20]. Lb Z strain displayed lipolytic character larger than that reported by Lactobacillus plantarum, sakei and curvatus strains isolated from saucisson sec [20]. The lipolytic action of lactic acid bacteria plays a role in the aromatization of the product by producing aromatic volatile compounds [15]. Lb Z -strain proved to be more active on Staphylococcus aureus and Pseudomonas aeruginosa strain unlike the results of [20]. According to $[23,24]$, if the inhibition halo disappears in the presence of the action of proteolytic enzyme, the inhibitory agent is protein in nature; but if it persists after the action of two enzymes used, there is a high probability that the agent was not proteinaceous i.e. a bacteriocin. The loss of antimicrobial activity of supernatant after treatment with enzymes, indicates the sensitivity of the active compounds secreted by cultured strains. Because bacteriocins are by definition protein substances, they must be sensitive to at least one enzyme. As a result, the sensitivity to proteolytic enzymes is the main criterion in their characterization [25]. Bacteriocins are produced by the majority of lactic acid bacteria isolated from raw fermented sausage, including the species Lactobacillus sakei, and Lactobacillus curvatus [26]. Its are also active toward other lactic acid bacteria and other pathogenic strains such as Listeria monocytogens, Staphylococcus aureus, Clostridium perfringens [27].

\section{Conclusion}

Our study focuses on the selection of indigenous lactic starters to ensure the organoleptic and hygienic nature of the desired product quality. The challenge is to isolate and characterize 'Kaddid' most dominant strain of the genus Lactobacillus which allows the selection of lactic ferments of industrial interest. The study allowed us to isolate 4 strains of the Lactobacillus genus, the species Lactobacillus sakei Lb Z turns the most efficient given its ability to grow in the presence of different concentrations of $\mathrm{NaCl}$ at different 
temperature, low $\mathrm{pH}$; as well as its fermentation profile and its antimicrobial activity due to different inhibitory substances

In conclusion, it seems possible to direct the microbial ecology of a processed product to improve its hygiene and sensory quality. In alignment with this work, other studies must be conducted such as the annotation of the genome of Lactobacillus sakei. In this analysis of the genome, we will identify several characteristics that allow us to understand why this bacterium is implanted, develops and survives on the meat after salting and drying. This analysis can reveal clues to understanding how Lactobacillus sakei supplants other bacterial species. Several steps need to be taken before the use of Lactobacillus sakei as a bio-conservative agent.

In perspective, it is possible to select lactic ferments from dominant lactic flora at the level of the "Kaddid" product, in this case Lactobacillus sakei, and consider combining them with one or two strains of Staphylococcus/Kocuria (flora of technological interest), isolated from the same product. From another perspective, reduce the levels of salt added in the production of meat products, and this is possible through a combination of "ferment lactic-salt", which will allow a finished product with hygienic properties.

\section{References}

[1] Albano, H., Carol, A., Van Reenen, Svetoslav, D., Diana Cruz, Luisa Fraga, Tim Hogg, Leon M. T. Dicks and Paula Teixeira. Phenotypic and genetic heterogeneity of lactic acid bacteria isolate from "Alheira", a traditional fermented sausage produced in Portugal. Meat Science. 2009, vol.82, 389-398.

[2] Ammor, M. S., Chevallier, L. and Dufour, E. Écologie microbienne dirigée au niveau des ateliers fermiers de salaison: un moyen de préserver la typicité des saucissons secs fermiers du Massif Central. In: Produits Alimentaires Fermiers. E. Dufour (Eds), ENITA. Lempdes. 2004, pp. 127-128.

[3] Beatriz Gómez-Salaa,, Carmen Herranza, Belén Díaz-Freitasb, Pablo E. Hernándeza, Ana Salab, Luis M. Cintasa, Strategies to increase the hygienic and economic value of fresh fish: Biopreservation using lactic acid bacteria of marine origin. International Journal of Food Microbiology, Volume 223, 16 April 2016, Pages 41-49.

[4] Maria João Fraqueza, Antibiotic resistance of lactic acid bacteria isolated from dry-fermented sausages. International Journal of Food Microbiology, Volume 212, 6 November 2015, Pages 76-88.

[5] De Man, J. C., Rogosa; M. and Sharpe, M. E. A medium for cultivation of Lactobacilli, Journal of Applied Bacteriology, Vol. 23, 1960, pp.130-135.

[6] John, G. Holt. Bergey's manual of systematic bacteriology, Williams \& Wilkins Ed, Vol.2 1986, pp. 965-1599.

[7] Hicham Labaoui, Laroussi El Moualdi, Mohammed El Yachioui, Mohammed Ouhssine. Sélection de souches de bactéries lactiques antibactériennes. Bull. Soc. Pharm. Bordeaux, 2005, 144, 237-250.

[8] Parente, E., Martuscelli M., Gardini F., Grieco S., Crudele M. A., Suzzi G. Evolution of microbial populations and biogenic amine production in dry sausages produced in southern Italy. J. Appl. Microbiol. 2001, 90, 882-891.

[9] Holt, J. G., Krieg, N. R., Sneath, P. H. A., Staley, J. T., and Williams, S. T., (eds., 1994). Bergey's Manual of Determinative Bacteriology, 9th ed., The Williams \& Wilkins Co., Baltimore.

[10] De Roissart, H., Luquet, F. M. Bactéries lactiques - Aspects fondamentaux et technologiques. Tome 1. Lorica. 1994, 605.

[11] Barefoot, S. F and Klaenhammer, T. R. Detection and activity ollactacin B., A bacteriocins produced by Lactobacillus acidophilus. Appl. Environ. Microbiol.1983, 45, pp. 1808-1815.

[12] Essid Ines, Maher Medini, Mnasser Hassouna. Technological and safety properties of Lactobacillus platarum strains isolated from a Tunisian traditional salted meat. Meat Science, 81, 2009, 203-208.

[13] Guiraud, J. P. Microbiologie Alimentaire. Dunod - RIA. 2003, 696.

[14] Saidi, N., Guessas, B., Bensalah, F., Badis, A., Hadadji, M., Henni, D. E., Prevost, H., and Kihal, M. Caractérisation des bactéries lactiques isolées du lait de chèvre des régions arides. J. Alg. Reg. Arides, 2002, 1: 1-11.

[15] Gençcelep H., Kaban G., Kaya M. Effect of starter cultures and nitrite levels on formation of biogenic amines in sucuk. Meat Sci. 2007, 77, 424- 430.

[16] Olesen, P. T. \&Stahnke L. H. The influence of Debaryomyceshanseniiand Candida utilis on the aroma formation in garlic spiced fermented sausages and model minces. Meat Science, 2000, 56, 357-68.

[17] Zagorec, M., Chaillou, S; Champomier-Vergès, M. C., Cornet, M. Lactobacillus sakei: recent developments and future prospects. Res. Microbiol. 2006, 153, 115-123.

[18] Ammor, M. S., Tauveron, G., Chevallier, L. and Dufour. Antibacterial activity of lactic acid bacteria against spoilage and pathogenic bacteria isolated from the same meat small-scale facility, 1-Screening and characterization of the antibacterial compounds. Food Control. Vol.17, 2006, pp. 456-461.

[19] Penaud, S. Analyse de la séquence génomique et étude de l'adaptation à l'acidité de Lactobacillus delbrueckii ssp bulgaris ATCC11842. Thèse de Doctorat en Génétique, sous la direction de Mme Emmanuelle Maguin de l'Institut National Agronomique de Paris-Gignon, 2006, 268p.

[20] Ammor, M. S. and Baltasar, M. Selection criteria for lactic acid bacteria to be used as functional starter cultures in dry sausage production, An update. Meat Science. Vol. 76, 2007, pp. 138-146.

[21] Lücke, F. K., Utilisation of microbes to process and preserve meat. Meat Science. 2000, Vol.56, 105-115.

[22] Gevers, D., Danielsen, M., Huys, G., and Perreten, P. Molecular characterization of tet (M) genes in Lactobacillus isolates from different types of fermented dry sausage. Applied and Environmental Microbiology, 2003, 69, 12701275.

[23] Callewaert, R., and De Vuyst, L. Bacteriocin production with Lactobacillus amylovorus DCE 471 is improved and stabilized by fed-batch fermentation. Appl. Environ. Microbiol.2000, 66: 606-613. 
[24] Aslim, B. Yuksekdag, Z. N., Sarikaya, E. and Beyatli, Y. Determination of the bacteriocinlike substances produced by some lactic acid bacteria isolated from Turkish deary products. LWT 38, 2005, pp. 691-694.

[25] Cintas, L. M., M. P. Casaus, C. Herranz, I. F. Nes y P. E. Hernández (2001). Review: Bacteriocins of Lactic Acid Bacteria. Food Sci. Tech. Int., 7: 281-305.
[26] Tichaczek, P. S., Nissen-Meyer, J., Nes, I. F., Vogel, R. F., Hammes, W. P., Characterisation of the bacteriocinscurvacin A from Lactobacillus curvatu LTH1174 and sakacin P from L. sake LTH673. Syst Appl Microbiol. 1992, 15:460-468.

[27] Ayemrich, M. T., Garriga, M., Monfort, J. M., Nes, I. and Hugas, M. Bacteriocin-producing lactobacilli in Spanish-style fermented sausages, characterization of bacteriocins. Food Microbiology. Vol. 17, 2000, pp. 33-45. 